\title{
Uma análise sobre as categorias de desumanização do sujeito entre as personagens negras na obra Úrsula, de Maria Firmina dos Reis
}

DOI: http://dx.doi.org/10.21165/el.v48i2.2245

\section{José Gomes Pereira'}

\section{Resumo}

Este trabalho tem por objeto um estudo sobre as categorias de desumanização do sujeito oprimido, identificadas através do discurso do colonizador em relação às personagens negras, na obra Úrsula, da escritora maranhense Maria Firmina dos Reis. No ano de 1859, em pleno regime escravocrata, Maria Firmina tornou-se a primeira escritora afrodescendente a publicar um romance no Brasil, livro esse revelador de uma dupla ousadia: a primeira, de ter sido escrito por uma mulher, e, a segunda, de ter marcas abolicionistas em sua narrativa. Uma importante contribuição para as análises está no episódio das memórias de uma personagem chamada Mãe Susana, que, além de relembrar o período em que os negros foram trazidos à força para as terras brasileiras, também vai contestar os conceitos europeus de alforria e liberdade. Por conta desses detalhes históricos e antropológicos, serão utilizados, num quadro teórico-metodológico, os estudos pós-coloniais de Frantz Fanon e os conceitos de identidade de Stuart Hall.

Palavras-chave: memórias; negro; escravidão.

1 Universidade do Estado de Mato Grosso do Sul (UEMS), Dourados, Mato Grosso do Sul, Brasil; colhudopai@hotmail.com; http://orcid.org/0000-0002-0632-0334 


\title{
An analysis about the categories of dehumanization of the subject among the black characters in the work of Úrsula, by Maria Firmina dos Reis
}

\begin{abstract}
This work has for object a study on the categories of dehumanization of the oppressed subject, identified through the settler's speech in relation to the black characters, in the work Ursula, by Maria Firmina dos Reis, a writer from Maranhão. In the year 1859, in the slave regime, Maria Firmina became the first African-Brazilian writer to publish a novel in Brazil, this book reveals a double daring: the first, to have been written by a woman, and, second, to have abolitionists marks in the narrative. An important contribution to the analyses is the episode of memoirs of a character called Mother Susana, who, in addition to the period in which blacks were brought to the Brazilian lands, will also contest the European concepts of freedom and liberty. On account of these historical and anthropological details, will be used in a theoretical methodological framework, postcolonial studies of Frantz Fanon and the concepts of identity of Stuart Hall.
\end{abstract}

Keywords: identity; memories; black people; slavery.

\section{Introdução}

Maria Firmina dos Reis nasceu em São Luís do Maranhão em 11 de outubro de 1825, registrada como filha de João Pedro Esteves e Leonor Felipe dos Reis, tendo morrido em 1917, na vila de São José de Guimarães, no município de Viamão. No ano de 1859, publicou o romance Úrsula. Em 1871, veio a público sua coletânea de poemas intitulada Cantos à beira-mar. Também foi autora do conto "A escrava", no ano de 1887. No ano de 1888, compôs o Hino da Libertação dos Escravos, com letra e música. Ela recebeu educação escolar da tia materna, obtendo ajuda de seu primo, o escritor e gramático Sotero dos Reis.

No ano seguinte ao da publicação de seu romance Úrsula, houve, na capital de São Luís, a menção de sua obra, registrada como anúncio no jornal $A$ Moderação, segundo apontou Filho (1975, p. 33):

\footnotetext{
"Crônica Semanária" ÚRSULA - Acha-se à venda na Tipografia do Progresso, este romance original brasileiro, produção da exma. Sra. D. Maria Firmina dos Reis, professora pública em Guimarães. Saudamos a nossa comprovinciana pelo seu ensaio, que revela de sua parte bastante ilustração; e, com mais vagar emitiremos a nossa opinião, que desde já afiançamos não será desfavorável à nossa distinta comprovinciana. 11 de agosto de 1860.
} 
Esse é um registro histórico que comprova não apenas que a obra foi publicada, como também revela detalhes sobre o local onde ela estava sendo vendida, a profissão da autora e de onde ela era natural. Ao se abrirem as páginas do livro, via-se, então, uma narrativa romântica, ideologicamente abolicionista, esteticamente com viés gótico, cujos diálogos muito se assemelhavam aos das novelas de cavalaria. Duas novidades estavam sendo acrescentadas naquele momento: primeira, não era de um escritor branco a autoria, Maria Firmina era afrodescendente; segunda, não havia sido um homem o seu autor, a obra Úrsula fora escrita por uma mulher.

Quando identificamos esses dois elementos, entendemos que a escritora Maria Firmina dos Reis estava diante de um feito que talvez nem ela mesmo teria a percepção do pioneirismo de sua obra, muito menos da projeção ideológica que traria para os estudos posteriores. O primeiro fato, o de ser mulher, e o segundo, o de ser afrodescendente, já Ihe renderiam, no mínimo, certa especulação pública, com ares nada discretos de preconceito. Sobretudo, esses dois fatores aliados ao conteúdo abolicionista, fazem desta obra um marco na literatura brasileira, exatamente por colaborar também com a história do nosso povo.

Na esfera internacional, o Brasil de Maria Firmina dos Reis estava sendo bastante criticado pela manutenção do modelo escravocrata, considerado ultrapassado, além disso, antiquado para as pretensões dos Estados Unidos, Inglaterra e demais nações europeias, cuja força de trabalho era remunerada. Tal situação impedia que a demanda capitalista aqui chegasse com o propósito de se estabelecer. Para que isso fosse feito também era necessário que um governo republicano fosse implantado, o que de certa forma não estava sendo tão difícil de ocorrer, em virtude do desgaste sofrido pela imagem da monarquia nas últimas décadas.

No plano das ideias, destacamos que o pensamento das elites da sociedade maranhense, na época, era preconceituoso, sem espaço para a intelectualidade feminina, inclusive na produção literária. Reproduzia-se, naquele período, a concepção de que o negro, de fato, não se tratava de um ser humano, e se acaso fosse, pertenceria a uma categoria inferior, uma espécie de sub-humano. Se por um lado tínhamos pensadores racistas, por outro, tínhamos os abolicionistas, mesmo assim, as marcas de preconceito em relação ao afro podiam ser notadas nessas duas esferas de pensamento.

Por causa desses fatores, estudar o romance Úrsula pode contribuir para entendermos a história do povo brasileiro, ainda influenciado até os dias atuais quer seja pela temática do preconceito contra as raízes afrodescendentes, como também pelo desconhecimento da história e dos valores do negro em nossa sociedade. Nesse caso, eis a essência da obra: é o próprio negro quem conta sobre a sua história. Vale lembrar que todas as nossas grandezas patrimoniais na área da cultura, religião, linguagem, música, além de manifestações outras, devem-se a essas relações. 
Trataremos sobre as dimensões sociais apresentadas no desenrolar da narrativa e observaremos a novidade proposta pela obra de Maria Firmina dos Reis: o negro com voz própria. Observaremos como se processou essa interação na cadeia sentimental dos relacionamentos com as demais personagens. Também exploraremos a dinâmica da equivalência, isto é, os elementos qualificativos de personalidade e de comportamento das personagens negras que chegam a se equivaler no mesmo patamar de igualdade aos das personagens brancas.

Algumas vezes, neste trabalho, serão utilizadas as expressões colonizador e colonizado. Ambas derivam da definição de colonialismo de Bonnici (2009), segundo o qual, todo o centro constrói sua periferia, num binômio centro/margem, ou, em outras palavras, ocorre uma separação entre colônia, onde estão os que dominam, e no outro lado, o colonizado, que é a parte correspondente aos povos conquistados. Conforme veremos neste estudo, Memmi (2007) também se apropriou desse conceito e suas contribuições foram aproveitadas em determinadas análises. Nesse sentido ideológico é que utilizamos os conceitos de Fanon (2008, p. 34), ao defender a tese de que "Todo povo colonizado - isto é, todo povo no seio do qual nasceu um complexo de inferioridade devido ao sepultamento de sua originalidade cultural - toma posição diante da linguagem da nação civilizadora, isto é, da cultura metropolitana."

O processo de exploração do homem para com o seu semelhante se desenvolveu, sob a ordem dialética do dono do poder contra o pobre oprimido, desestabilizando as relações humanas de igualdade, respeitabilidade e dignidade, dando lugar a uma conjuntura desumana tanto da parte de quem explora quanto da parte de quem é explorado. É como se o homem se afastasse cada vez mais de sua essência humana, inaugurando um sistema de desumanidade. Por essa razão, utiliza-se, neste trabalho, o termo desumanização, de acordo com o prefácio do filósofo Jean-Paul Sartre em uma das obras do escritor Albert Memmi (2007, p. 29-30):

\footnotetext{
Só há um meio: rebaixar o colonizado para engrandecer a si mesmo, recusar aos nativos a qualidade de homem, defini-los como simples privações. Isso não será difícil uma vez que, justamente, o sistema os priva de tudo; a prática colonialista gravou a idéia colonial nas próprias coisas; é o movimento das coisas que designa a um só tempo o colono e o colonizado. [...] o terror e a exploração desumanizam, e o explorador se sente autorizado por desumanização a explorar ainda mais.
}

Propomos, assim, um estudo dividido em três estágios sobre a desumanização do sujeito colonizado: $1^{\circ}$ ) A diáspora: estudaremos as tensas relações de expatriação dos africanos, desde o confinamento em navios negreiros até a venda e escravização em terras brasileiras; $2^{\circ}$ ) 0 duplo conceito de liberdade: abordaremos a incorporação do 
discurso do colonizador europeu sobre tal tema na mente do colonizado; $3^{\circ}$ ) As relações: analisaremos as dinâmicas de opressão e poder entre colonizador e colonizado. No último tópico, estudaremos o processo contrário ao da desumanização, isto é, o negro com qualidades e virtudes equivalentes ao branco.

\section{A diáspora: o início da desumanização}

Quando Said (2007) apontou que entre Ocidente e Oriente ocorre uma relação de poder ou de dominação, sob a forma de um caráter hegemônico, o mesmo pode ser constatado no recapitular dos fatos narrados pelas memórias de uma personagem chamada Mãe Susana, ao abordar a saída forçada dos africanos de seu continente rumo à escravidão. É a diáspora territorial denominada por Bhabha (2007), sobre a qual Laraia (2014, p. 75) destacou:

\footnotetext{
Os africanos removidos violentamente do seu continente (ou seja, do seu ecossistema e do seu contexto cultural) e transportados como escravos para uma terra estranha habitada por pessoas de fenotipia, costumes e línguas diferentes, perdiam toda a motivação de continuar vivos. Muitos foram os suicídios praticados, e outros acabavam sendo mortos pelo mal que foi denominado de banzo. Traduzido como saudade, o banzo é de fato uma forma de morte decorrente da apatia.
}

Por causa disso utilizaremos o termo diáspora, no propósito de configurar relação de significado com a saída dos africanos de seu lugar de origem. Contribuindo para essa análise, houve um momento, dentro da narrativa, em que Mãe Susana revelou particularidades sobre a vinda forçada dos africanos ao Brasil. Para recuperar os detalhes de como tal fato se sucedera, a personagem se reportou à chegada do europeu em solo africano, desde a caça e captura até o transporte dos mesmos nos chamados navios negreiros. Antes disso, num primeiro instante, o jovem Túlio fez objeção à iniciativa declarada de Susana em relembrar como se deu o processo de escravidão. O diálogo a seguir marca a introdução dessas memórias: "- Ah! pelo céu! - exclamou o jovem negro enternecido - sim, pelo céu, para que essas recordações!?" (REIS, 2004, p. 115).

Conforme destaca o trecho acima, havia um constrangimento histórico por parte do personagem Túlio em relação às reminiscências do passado do seu povo: as dores das recordações eram incômodas a ele, o que nos leva a observar o motivo dessa objeção. Na verdade, como veremos mais tarde, estava projetada sobre Túlio a imagem de um negro com as boas qualidades dos brancos. A narração é enriquecida com detalhes acerca de sua bondade a partir do primeiro capítulo do livro, quando o jovem escravo presta assistência a um desconhecido, que no desenrolar da narrativa se tornará seu grande amigo - o nobre Tancredo; além de lhe outorgar a liberdade por uma carta de alforria, vai também se enamorar de uma senhorita chamada Úrsula. 
Essa negativa de Túlio não seria a tentativa de se legitimar uma espécie de esquecimento social, pois mais parece combinar com o perfil de sua personalidade do que com a vontade de negar os fatos ocorridos com o seu povo. Ele representa a jovem geração afrodescendente na obra, enquanto Mãe Susana tipifica a geração mais antiga. Ambas estão ligadas por um elo de dependência: o jovem que precisa dos conselhos e das memórias da matriarca para não se esquecer de quem ele era e de onde viera, e a anciã respeitosamente tida como a mãe de todos, cujo passado, ao ser relembrado, perpetua na pessoa de Túlio suas marcas de ancestralidade, que exercem uma espécie de poder de renovação à medida em que vão sendo assimiladas.

A conjuntura dessa interação decorre da necessidade geral de se apropriar das memórias coletivas do povo, as quais, nesse contexto, passam a se constituir como patrimônio imaterial da sociedade, de sorte que o lembrado e o esquecido revelam-se como mecanismos de manutenção do poder, conforme considerou Le Goff (2003, p. 422):

Do mesmo modo, a memória coletiva foi posta em jogo de forma importante na luta das forças sociais pelo poder. Tornar-se senhores da memória e do esquecimento é uma das grandes preocupações das classes, dos grupos, dos indivíduos que dominaram e dominam as sociedades históricas. Os esquecimentos e os silêncios da história são reveladores destes mecanismos de manipulação da memória coletiva.

Desta forma, conseguimos compreender a relevância dada pela personagem com maior vivência em expor os detalhes históricos de seu povo, confirmando, assim, que o processo de escravização poderia ter levado muita coisa de sua gente, menos as suas memórias. Dentro dessa retrospectiva, analisaremos duas circunstâncias: a circunstância da captura e, em seguida, a do transporte. Nesse depoimento dado por Mãe Susana há particularidades sobre como se deu o processo de captura quando ela habitava sua terra de origem no continente africano:

Ainda não tinha vencido cem braças de caminho, quando um assobio, que repercutiu nas matas, me veio orientar acerca do perigo iminente, que aí me aguardava. E logo dois homens apareceram, e amarraram-me com cordas. Era uma prisioneira - era uma escrava! Foi embalde que supliquei em nome de minha filha, que me restituíssem a liberdade: os bárbaros sorriam-se das minhas lágrimas, e olhavam-me sem compaixão. Julguei enlouquecer, julguei morrer, mas não me foi possível... a sorte me reservava ainda longos combates. Quando me arrancaram daqueles lugares, onde tudo me ficava - pátria, esposo, mãe e filha, e liberdade! meu Deus! 0 que se passou no fundo de minha alma, só vós o pudestes avaliar!... (REIS, 2004, p. 116). 
Conforme observamos, a desumanidade perpetrada pelos dois homens, personagens da história, contra a indefesa mulher acabou por revelar como se dava a caça aos seres humanos em território africano. O uso do assobio como chamariz, também trouxe um comentário da personagem. Esse comentário pode ser compreendido como um elemento marcador de pressuposição, ou seja, um aviso ao leitor que algo de errado estava por acontecer no desenrolar da cadeia narrativa. Utilizando-se desse recurso, a escritora mostrou a dicotomia entre liberdade e escravidão, no contexto em que a súplica da mesma não havia sido atendida.

Em seguida, temos o depoimento sobre como se deu o processo de transporte dela e dos demais companheiros africanos:

\begin{abstract}
Meteram-me a mim e a mais trezentos companheiros de infortúnio e de cativeiro no estreito e infecto porão de um navio. Trinta dias de cruéis tormentos, e de falta absoluta de tudo quanto é mais necessário à vida passamos nessa sepultura até que abordamos as praias brasileiras. Para caber a mercadoria humana no porão fomos amarrados em pé e para que não houvesse receio de revolta, acorrentados como os animais ferozes das nossas matas, que se levam para recreio dos potentados da Europa. Davam-nos a água imunda, podre e dada com mesquinhez, a comida má e ainda mais porca: vimos morrer ao nosso lado muitos companheiros à falta de ar, de alimento e de água. É horrível lembrar que criaturas humanas tratem a seus semelhantes assim e que não Ihes doa a consciência de levá-los à sepultura asfixiados e famintos! Muitos não deixavam chegar esse último extremo - davam-se à morte. Nos dois últimos dias não houve mais alimento. Os mais insofridos entraram a vozear. Grande Deus! Da escotilha lançaram sobre nós água e breu fervendo, que escaldou-nos e veio dar a morte aos cabeças do motim. (REIS, 2004, p. 117).
\end{abstract}

Ao relatar como eram tratados os negros retirados à força do continente africano, conforme pode ser observado no trecho acima, a personagem Mãe Susana - na continuidade da descrição dos fatos - permite-nos enxergar o irônico itinerário da liberdade rumo à escravidão. De agora em diante, é a descrição de cinco categorias de infortúnio: $1^{a}$ ) localidade: mercadoria humana no porão - o porão era a parte menos nobre do navio, onde ficavam as coisas, contudo ali estavam seres humanos num processo de coisificação; $2^{a}$ ) temporalidade: trinta dias - os escravos tinham que suportar a severidade do confinamento durante um mês; $3^{a}$ ) modalidade: em pé e amarrados com correntes - para que coubesse a maior quantidade possível dos mesmos, deveriam, pois, permanecer em tal posição para que não se rebelassem ou tentassem fugir, além disso, ficavam amarrados, semelhantemente ao transporte de animais; $4^{\mathrm{a}}$ ) quantidade: 
trezentos - ao leitor é fornecido um número, que estava associado a um valor de mercado, ou seja, uma noção quantitativa que explica o sentido da metáfora mercadoria humana; $5^{a}$ ) morte - essa quinta categoria de infortúnio aponta tanto o suicídio quanto o fim da vida em decorrência dos maus-tratos sofridos. O episódio da água fervente misturada com breu sinaliza o uso de uma sequência gradativa de tortura.

O discurso ideológico do colonizador está atrelado a essas instâncias desestabilizadoras da dignidade humana, inaugurando os conceitos de escravidão e liberdade, dominador e dominado, senhor e escravo. O eixo dessas relações permite-nos enxergar a lógica do discurso de quem, pela força da opressão, se manteve no poder. Por outro lado, quando em Úrsula a parte oprimida relata a sua versão dos fatos, acaba, assim, revelando uma nova ordem do discurso. Dentro de tal perspectiva, encaixa-se o estudo do duplo conceito de liberdade, assunto que abordaremos em seguida.

\section{O duplo conceito de liberdade: a desumanização no campo das ideias}

"A Preta Susana" é o título do nono capítulo do livro Úrsula e sua sequência narrativa referese a uma personagem homônima que iniciou um diálogo com um jovem negro escravo chamado Túlio, considerado como um filho para a mesma. Em relação aos negros do enredo, ela era uma espécie de matriarca, o símbolo da experiência e a referência de sabedoria para eles. No referido capítulo, Túlio começou a se despedir dela, dizendo que iria acompanhar o senhor Tancredo - o jovem cavaleiro que fora socorrido pelo escravo no primeiro capítulo do livro e, mais tarde, passou a se tornar seu grande amigo.

Para entendermos melhor essa amizade - que se estendia em tons de cumplicidade precisamos voltar ao capítulo terceiro, onde foram construídas as razões dessa relação. O cavaleiro Tancredo, assim que se recuperara do acidente ocorrido com o próprio cavalo, entregou a Túlio uma determinada quantia em dinheiro para que este finalmente pudesse adquirir a sua alforria, conforme comprova o trecho abaixo: "Tinha-se alforriado. O generoso mancebo assim que entrou em convalescença dera-lhe dinheiro correspondente ao seu valor como gênero, dizendo-lhe: - Recebe, meu amigo, este pequeno presente que te faço, e compra com ele a tua liberdade." (REIS, 2004, p. 42).

Por causa desse episódio ocorrido anteriormente, Túlio, no nono capítulo, começou a se despedir da matriarca, a qual passou a entender o que se passava quando o jovem revelou o que the havia acontecido. Eram valores sinceros de felicidade, gratidão e lealdade que passaram, a partir de então, a integrar uma espécie de nova vida para o negro alforriado. O trecho abaixo comprova o fato e ajuda a reacender na mente de Mãe Susana as lembranças do passado africano: 
-Tu! tu livre? ah não me iludas! - exclamou a velha africana abrindo uns grandes olhos. Meu filho, tu és já livre?...

- Iludi-la! - respondeu ele, rindo-se de felicidade - e para quê? Mãe Susana, graças à generosa alma deste mancebo sou hoje livre, livre como o pássaro, como as águas; livre como éreis na vossa pátria.

Essas últimas palavras despertaram no coração da velha escrava uma recordação dolorosa, soltou um gemido magoado, curvou a fronte para a terra, e com ambas as mãos cobriu os olhos. (REIS, 2004, p. 114).

A partir desse momento, a narrativa foi marcada pelo questionamento sobre o conceito de liberdade. Ela criticou o que o jovem tinha como definição sobre o significado de ser livre, fazendo-lhe lembrar, através de seus relatos de memórias, que a liberdade de fato ela experimentou quando vivera em sua terra natal, no continente africano. A liberdade de Túlio havia sido comprada por determinada soma em dinheiro, advindo das mãos de um branco, mesmo que bem-intencionado, e manifesta em uma carta de alforria. O discurso dela enfatizava que dinheiro algum poderia comprar a liberdade do negro, pois se havia alguém que sabia o que era ser livre, esse alguém era o próprio negro expatriado à força da África. Podemos comprovar isso no trecho abaixo:

- Sim, para que estas lágrimas?!... Dizes bem! Elas são inúteis, meu Deus; mas é um tributo de saudade, que não posso deixar de render a tudo quanto me foi caro! Liberdade! liberdade....ah! eu a gozei na minha mocidade! - continuou Susana com amargura - Túlio, meu filho, ninguém a gozou mais ampla, não houve mulher alguma mais ditosa do que eu. Tranquila no seio da felicidade, via despontar o sol rutilante e ardente do meu país, e louca de prazer a essa hora matinal, em que tudo aí respira amor, eu corria às descarnadas e arenosas praias, e aí com minhas jovens companheiras, brincando alegres, com o sorriso nos lábios, a paz no coração, divagávamos em busca das mil conchinhas, que bordam as brancas areias daquelas vastas praias. (REIS, 2004, p. 115).

Conforme verificamos nas palavras proferidas por Mãe Susana, estava sendo introduzida, naquele momento, uma espécie de diálogo psicológico intrafamiliar, conduzido pelas dores da saudade. Esse diálogo serve como base para afirmarmos que o negro não escolheu ser escravizado, como se tivesse sido voluntariamente entregue à escravização, posto que a liberdade fora-Ihe usurpada e substituída pelas correntes e pela chibata. 0 conceito de liberdade para Mãe Susana já não possuía o mesmo significado para Túlio. 
Por causa disso é que essas memórias da África, recuperadas pela matriarca da obra de Maria Firmina dos Reis, também podem ser consideradas como memórias de resistência. Ao observarmos o negro que talvez não tenha participado in loco desse acontecimento de diáspora, constatamos que a concepção de liberdade contida em seu discurso distanciase do perfil de seus antepassados e se aproxima do modelo pretendido pelos europeus. É a ideologia do colonizador sendo assimilada pelo colonizado, de acordo com o que Memmi (2007, p. 125) destacou:

\begin{abstract}
A acusação o perturba e o inquieta na mesma proporção em que admira e teme seu poderoso acusador. Será que este não tem uma certa razão?, murmura. Será que não somos mesmo um pouco culpados? Preguiçosos, já que temos tantos ociosos entre nós? Medrosos, já que nos deixamos oprimir? Desejado, difundido pelo colonizador, esse retrato místico e degradante termina, em certa medida, por ser aceito e vivido pelo colonizado. Ele ganha assim uma certa realidade, contribuindo para o retrato real do colonizado. Esse mecanismo é conhecido: trata-se de uma mistificação. A ideologia de uma classe dirigente, como se sabe, se faz adotar em larga escala pelas classes dirigidas.
\end{abstract}

Nesse sentido, a obra Úrsula serve de parâmetro para avaliarmos a realização desse mecanismo de mistificação, provando que houve uma ressignificação por parte do pensamento, pois para que o processo de colonização se mantivesse, era preciso que o colonizado pensasse sobre o conceito de liberdade, segundo a ótica do branco e não conforme o significado original do qual fazia parte o arcabouço de memórias de seus antepassados. Por outro lado, a obra Úrsula, diferente de outros romances de sua época, permite ao leitor uma observação detalhada tanto da visão do colonizador, exposta em seu discurso, quanto da visão do colonizado, cujas vozes não haviam sido passadas pelo processo do silenciamento.

Indiferente a qualquer discussão sobre o duplo conceito de liberdade, temos um novo Túlio, pelas palavras dele mesmo: livre. Essa auto-concepção do estar livre elevou ainda mais o seu apreço para com o bom cavaleiro. Mesmo depois de alforriado, Túlio manteve um padrão de comportamento de escravo, o que se estendeu além da manutenção de um hábito, chegando ao patamar da permanência de uma condição. A benevolência do senhor Tancredo, que implicou na alforria de Túlio, trouxe para aquele benfeitor mais do que um amigo, um novo escravo, porém não mais escravizado pela ordem da chibata, do tronco ou da senzala, ao contrário, um amigo escravo, preso pelo sentimento de gratidão. Túlio e Tancredo estavam unidos não apenas nas ações, como também nos pensamentos, desde o primeiro capítulo do livro. 
Graças à interferência das memórias de Mãe Susana, o repertório discursivo acerca do conceito de liberdade não é unilateral, logo, apresenta os dois lados: o modelo propagado pelo colonizador e a versão do colonizado. A narração, por conseguinte, a partir dessa desestabilização da ordem do discurso, passa a agregar valores de humanidade e religiosidade. São esses fatores que desencadearão um efeito de questionamento e indignação na lógica da estrutura narrativa, quando temos, por exemplo, no plano das ideias, uma personagem negra remanescente da diáspora em território africano, sentindo saudades da sua época de liberdade, em contraponto ao tratamento desumano por ela sofrido. Essas questões conflituosas entre o branco opressor e o negro oprimido serão tratadas a seguir.

\title{
4. Relações de desumanização entre colonizador e colonizado
}

O último estágio de desumanização do sujeito colonizado projeta sobre a figura deste a degeneração de sua dignidade e de sua liberdade. A dignidade do negro passou a não lhe pertencer mais e a sua liberdade fora usurpada a partir do momento em que ele passou a ter um dono. Esse duplo processo degenerativo desencadeou, por sua vez, a perda das construções identitárias, que foram reconfiguradas à proporção da necessidade de seu novo estilo de vida, conforme as palavras de Stuart Hall (2011, p. 13):

\begin{abstract}
O sujeito assume identidades diferentes em diferentes momentos, identidades que não são unificadas ao redor de um "eu" coerente. Dentro de nós há identidades contraditórias, empurrando em diferentes direções, de tal modo que nossas identificações estão sendo continuamente deslocadas. Se sentirmos que temos uma identidade unificada, desde o nascimento até a morte é apenas porque construímos uma cômoda história sobre nós mesmos ou uma confortadora "narrativa do eu".
\end{abstract}

Considerando que essa reconfiguração identitária está inserida por elementos sociais, entendemos que a mesma passou a assumir uma perspectiva ideológica hegemônica, o que patrocinou a tese de superioridade do colonizador e inferioridade do colonizado. Souza (1983) constatou que a sociedade branca utilizou-se da escravidão para promover a transformação do africano em escravo e a definição do negro como raça, ou seja, o regime escravocrata favoreceu a demarcação das linhas sociais, reposicionando o negro de um lado e o branco do outro.

É nesse contexto que passamos a estudar as relações entre o colonizador e o colonizado, conforme elucidou Memmi (2007, p. 127): 


\begin{abstract}
O laço entre o colonizador e o colonizado é, assim, destrutivo e criador. Ele destrói e recria os dois parceiros da colonização: um é desfigurado como opressor, como ser parcial, incivil, trapaceiro, preocupado unicamente com seus privilégios, com sua defesa a qualquer preço; o outro como oprimido, refreado em seu desenvolvimento, compondo com seu próprio esmagamento. Assim como o colonizador é tentado a aceitar-se como colonizador, o colonizado é obrigado, para viver, a aceitar-se como colonizado.
\end{abstract}

Dentro dessas relações estabelecidas pelo colonialismo, verificamos uma hipotética metamorfose do homem: o colonizado, à medida que foi sendo massacrado e oprimido, começou a se afastar da imagem de ser humano, por causa do tratamento que recebera e da reflexão mental sobre sua própria existência; o colonizador, conforme massacrava e oprimia, foi também se descaracterizando de sua forma humana, passando a assumir outra, identicamente animalesca. Seguiu-se, nestas proporções, uma recíproca escala de degradação: os malefícios decorrentes da desumanidade tanto afetaram as vítimas da escravidão como os seus algozes. Assim, diante da ótica do colonizado, observemos a ordem de prisão à Mãe Susana:

- Levem-na! - tornou acenando para Susana. - Miserável! pretendeste iludir-me... saberei vingar-me. Encerrem-na em a mais úmida prisão desta casa, ponha-se-lhe corrente aos pés, e à cintura, e a comida seja-lhe permitida quanto baste para que eu a encontre viva. Susana ouviu tudo isso com a cabeça baixa: depois ergueu-a, fitou os céus, onde a aurora começava a pintar-se, como se intentasse dar à luz seu derradeiro adeus, e de novo volvendo para o chão, exclamou:- Paciência! (REIS, 2004, p. 192).

Dentro dessa esfera conflituosa que sinalizou e introduziu, no trecho acima, a materialização da maldade sob a forma de tortura e dor em relação à personagem Mãe Susana, deparamo-nos com as metáforas. Essas figuras de linguagem podem fornecer auxílio e suporte interpretativo ao investigarmos as personagens e seus papéis dentro da narrativa. Por conta disso, a partir desse momento estudaremos a degradação da pessoa humana segundo a abordagem das metáforas e suas implicações dentro da narrativa. Para organização de critério, elas passam a ser chamadas de metáforas da desumanização.

A primeira metáfora é a figura do animal: repetiu-se, nesse episódio, a animalização do homem, como já havia acontecido na cena do navio negreiro, sob a forma das correntes e a escassez de comida, acrescentando-se, agora, o lugar úmido, com o propósito didático de ensinar ao colonizado que, para o colonizador, o mesmo não passava de um animal, ou talvez até, pior do que isso. A segunda metáfora é a figura da cabeça baixa: Esse é o 
símbolo da escravidão, mostrando o que significava ser escravo. O colonizado de cabeça baixa representava a submissão e sinalizava que a única vontade que existia naquele contexto era a do colonizador.

Também podemos analisar o perfil do colonizador, utilizando dois processos figurativos: a metáfora da fera e a metáfora do sorriso infernal. Sobre a primeira figura encontramos o seguinte:

\begin{abstract}
Fernando tinha vivido solitário, e desesperado com essa luta terrível do coração com o orgulho: e esses desgostos íntimos, que ele próprio forjava, o tinham embrutecido, e tanto lhe afearam o moral, que era odiado, e temido de quantos o praticavam ou conheciam de nome. Ele tornara-se odioso e temível aos seus escravos: nunca fora benigno e generoso para com eles: porém o ódio, e o amor, que the torturavam de contínuo, fizeram-no uma fera - um celerado. (REIS, 2004, p. 143).
\end{abstract}

Conforme podemos observar, o Comendador Fernando personificava um animal feroz, provando assim que, da mesma maneira que o processo de desumanização do sujeito colonizado foi configurado, isso também se aplicou ao colonizador: o ódio era uma forma de promover o afastamento social, o caráter embrutecido favorecia a característica da não conversa, do não diálogo, da impossibilidade do acordo, e a vida solitária colaborava para que sua representação de fera se tornasse autêntica, pois quanto mais isolada do convívio estiver a fera, mais perigosa ela é. Era nessa fera em que consistia sua metamorfose, e esse estágio de animal o identificava com os escravos animalizados segundo o tratamento desumano que recebiam.

Além disso, diante dos escravizados havia a temível figura do carrasco que oprimia, açoitava e matava, que na obra Úrsula era o feitor. Contudo, bem sabiam os negros escravos da existência daquele que estava por trás de tudo isso, cuja palavra de comando ordenava os atos de desumanidade, isto é, o Comendador Fernando, o senhor dos escravos. Dentro desse contexto encaixava-se o deboche, o desejo de se alegrar com o sofrimento do outro, a que chamaremos de metáfora do sorriso infernal, conforme podemos comprovar no trecho seguinte: "Então um sorriso infernal Ihe arregaçou o lábio superior, e seu rosto ficou hediondo." (REIS, 2004, p. 192).

Após analisarmos tanto a primeira quanto a segunda figuras, entendemos que a lógica das relações entre colonizador e colonizado veio confirmar a mencionada metamorfose do homem. Isso permite-nos enxergar a desumanização como sendo um fator recíproco e doentio, ou seja, ela passou a se constituir como argumento que comprova a tese de que com a escravidão - denunciada e condenada por Maria Firmina dos Reis - o homem se degenerou enquanto ser humano. Além disso, essa degeneração foi recíproca, 
pois animalizou tanto o opressor quanto o oprimido, e também doentia, por prejudicar a estabilidade da humanidade nas suas relações sociais. Sobretudo algo interessante chama a atenção na obra Úrsula: brancos e negros equiparados, desfrutando ambos de qualidades, sem a intenção de se sobrepor um em relação ao outro, o que veremos a seguir.

\title{
5. Desumanização: o processo reverso e o retorno à dignidade humana
}

Ao contrário de obras literárias da época, no período em que vigorava o Romantismo, o romance Úrsula valorizou a personagem negra, ao dar-lhe voz e oportunidade de expressão. Por meio do título Duas almas generosas, deu-se início ao primeiro capítulo da obra. O que chamou a atenção foi exatamente a forma pela qual esse título fora construído: preconizando a intencionalidade da autora ao elevar o padrão humano de belezas interiores de Túlio e de Tancredo. Este acabou precisando da boa vontade daquele, quando um acidente quase o matara, fato esse narrado com a exposição dos atributos psicológicos do escravo Túlio, conforme o trecho abaixo:

\begin{abstract}
O homem que assim falava era um pobre rapaz, que ao muito parecia contar vinte e cinco anos, e que na franca expressão de sua fisionomia deixava adivinhar toda a nobreza de um coração bem formado. O sangue africano refervia-lhe nas veias: o mísero ligavase à odiosa cadeia da escravidão. (REIS, 2004, p. 22).
\end{abstract}

Além dessas características que Ihe eram pertinentes, Túlio aliou-se à causa desafortunada de Tancredo, ou seja, passou a cuidar dele, oferecendo-lhe a atenção digna de um irmão. A partir desse momento não conseguimos mais enxergar entre eles nem barreiras de raça (branco ou negro), nem de situação (escravo ou livre). É nesse sentido que foi utilizado o termo almas no título, pois essa concepção conduziu-nos ao entendimento de que o relacionamento entre ambas as personagens havia atingido um alto nível de transcendentalidade, extrapolando as relações que as convenções sociais, pelo menos, buscavam aprisioná-los. Por causa disso, o leitor começa a perceber detalhes de equivalência e nobreza entre os dois amigos:

\footnotetext{
Apesar da febre, que despontava, o cavaleiro começava a coordenar suas ideias, e as expressões do escravo, e os serviços, que the prestara, tocaram-lhe o mais fundo do coração. É que em seu coração ardiam sentimentos tão nobres e generosos como os que animavam a alma do jovem negro: por isso, num transporte de íntima e generosa gratidão o mancebo arrancando a luva, que lhe calçava a destra, estendeu a mão ao homem que o salvara. (REIS, 2004, p. 25).
} 
Quanto ao exposto acima convém destacar duas coisas: a equiparação de sentimentalidade entre ambos os personagens e a humildade de Tancredo. Num primeiro momento, temos a comparação entre os bons sentimentos peculiares a Tancredo com o mesmo conjunto psicológico do qual também desfrutava Túlio. Num segundo momento, deparamo-nos com a atitude da retirada da luva na cena da mão que se estendia. A cortesia e a formalidade, ambas ensinadas como padrões de civilidade e de boa educação, desempenhavam um papel consensual entre a população branca. Não se esperava, porém, que um branco retirasse a própria luva para apertar a mão de um negro. A atitude de Tancredo elevou seu padrão de humanidade, em razão da humildade revelada em seu gesto.

Em qualquer outra obra do contexto de contemporaneidade a que a autora de Úrsula pertencia (até de escritores celebrados pela crítica, bem como de outros mais famosos do que ela), não se encontrava um herói branco com um equivalente negro, desfrutando das mesmas qualidades como honestidade, lealdade, fraternidade e atributos de beleza física. Primeiramente a escritora desconstruiu a imagem negativa do negro, para, a partir de então, reconstruir uma boa imagem. Para Bernd (1988), tal reversão de valores tem o propósito de desconstruir uma visão negativa que se tinha do negro e construir uma imagem positiva dele, afırmando e exaltando sua condição humana.

Seguindo essa mesma linha de pensamento, chegamos à ótica da alteridade, que segundo Fanon (2008) restava a esperança de existir uma nova humanidade, sem vencedores nem vencidos, sem dominadores nem dominados, onde a perspectiva de raça fosse substituída pela visão de si próprio no outro, olhando-se no outro, sentindo-se no outro. Isso é perceptível na obra, que propõe o resgate do senso de humanidade, que foi-se perdendo ao longo do processo de colonização, apresentando harmonia na interação entre os personagens Túlio e Tancredo.

Quando estudamos o perfil ideológico de Úrsula, entendemos o repúdio à escravidão através das marcas discursivas da religião. Isso porque, no contexto em que a obra foi escrita, convém lembrar que a aristocracia da época era composta por senhores de engenho, os quais ao mesmo tempo em que empregavam a mão de obra escrava, eram também católicos. Durante muito tempo a forma de se perpetuar no poder pretendida pelas oligarquias dava-se através do fortalecimento de suas relações com a Igreja, no caso, Igreja Católica. Se os senhores de engenho mantivessem boas relações com o clero, era, assim, Ihes assegurada a garantia da estabilidade no poder. Em Úrsula, o argumento levado em consideração para sustentar a tese de que a abolição era desumana, está fundamentado na ordem religiosa. A sociedade da época manifestava apreço e devoção aos preceitos do Cristianismo. Nessa obra, esses valores aparecem. Vejamos: 
Coitado do escravo! nem o direito de arrancar do imo peito um queixume de amargurada dor!!... Senhor Deus! quando calará no peito do homem a tua sublime máxima - ama a teu próximo como a ti mesmo -, e deixará de oprimir com tão repreensível injustiça ao seu semelhante! ... a aquele que também era livre no seu país... aquele que é seu irmão?! (REIS, 2004, p. 22).

Citando um dos dez mandamentos contidos na Bíblia, a autora destacou uma certa incongruência entre fé cristã e sua respectiva prática. Dentro dessa discrepância, levantouse o questionamento contra a escravidão com argumentos bem construídos. O ponto forte desse eixo de tensões foi o argumento segundo o qual o homem cristão não poderia escravizar o seu semelhante, por causa da desumanidade do ato e do afastamento desse mesmo homem da essência doutrinária do Cristianismo. Tal posicionamento de Maria Firmina conferiu-lhe uma postura ousada, conforme as palavras de Duarte (2004, p. 272):

\footnotetext{
Ressalte-se de início que não se trata de condenar a escravidão unicamente porque um escravo específico possui um caráter elevado. Trata-se de condenar a escravidão enquanto instituição. E a autora o faz partir do próprio discurso religioso oriundo da hegemonia branca, que afirma serem todos irmãos independentemente da cor da pele! Se pensarmos em termos do longínquo ano de 1859 e da longínqua província do Maranhão, poderemos aquilatar o quanto tal postura tem de avançado, num contexto em que a própria Igreja Católica respaldava o sistema escravista.
}

O leitor de Úrsula vai sendo preparado para o eixo ideológico da obra, familiarizandose com a ideia de que a escravidão é desumana, seus praticantes são doentios e suas vítimas são humilhadas. O romance apresentou a incoerência entre o discurso religioso de amor ao próximo que parecia não combinar com a força da chibata que oprimia e arrancava sangue. 0 ápice do romance está na proposta de se fazerem diferentes e mais humanas essas relações entre negros e brancos quando deparamo-nos com a interação entre as personagens.

\section{Considerações finais}

Os estudos aqui levantados ajudaram-nos a confirmar a tese de que essa obra de Maria Firmina dos Reis não se reportou ao negro apenas como um tema, entretanto outorgouIhe os atributos de sujeito da enunciação. A prova disso está na passagem da narrativa para o discurso direto, momento em que ele pôde contar sobre sua história a partir de um ponto de vista interno. Dentro desse ponto de vista peculiar a ele e a sua ancestralidade africana, fomos conduzidos às chamadas memórias. Encontrar o registro dessas memórias manteve o legado e constituiu-se como conteúdo de base que veio contribuir para os estudos a respeito do negro na literatura brasileira. 
Em relação a todos os estágios de desumanização analisados, observamos que cada um deles reafirmou o caráter destrutivo do processo de escravização, com sua potência máxima registrada no último estágio, quando estudamos as relações entre colonizador e colonizado. A constatação a que chegamos foi que o veneno da escravidão também fora nocivo aos seus manipuladores, uma vez que tanto a opressores quanto a oprimidos os estágios da degeneração humana foram contemplados, a tal ponto de ambos os lados, escravizador e escravizado, se identificarem na etapa final do processo.

A equiparação física e moral entre o escravo Túlio e o cavaleiro Tancredo constituiu o clímax do ideário da escritora, como se propusesse que o Brasil poderia escrever uma nova história, pacificando a tensa relação entre colonizador e colonizado. Esse também foi, conforme analisamos anteriormente, o chamariz temático da obra. Por essa razão, tal ideário a que chamamos de processo reverso à desumanização, deve ser observado como a palavra final: brancos e negros podem viver harmonicamente sem as agruras do poder do mais forte prevalecendo sobre o mais fraco. O ineditismo da personagem negra usufruindo das celebradas qualidades da personagem branca reforçou essa linha de pensamento.

O romance Úrsula, de Maria Firmina dos Reis, é, portanto, uma obra fundamental para se estudar não apenas a escravidão, mas também como se deu o processo de construções identitárias do negro africano em território brasileiro e suas reminiscências culturais contadas por ele mesmo. Não bastasse sua importância histórica por causa dos registros ali contidos, sua relevância literária credenciada pela estrutura temática e estética também deve ser considerada. São essas características que permitem-nos afirmar que este é um romance para o brasileiro entender melhor sobre si e sobre as raízes da nação a que faz parte.

\section{REFERÊNCIAS}

BERND, Z. Introdução à literatura negra. Porto Alegre: Mercado Aberto, 1988.

BHABHA, H. K. O Local da Cultura. Belo Horizonte: Editora UFMG, 2007.

BONNICI, T:;ZOLIN, L. O. Teoria Literária. Abordagens Históricas e Tendências Contemporâneas. 3. ed. Maringá: EDUEM, 2009.

DUARTE, E. de A. Maria Firmina dos Reis e os primórdios da ficção afro-brasileira. Posfácio. In: REIS, M. F. dos. Úrsula. A escrava. Florianópolis: Mulheres, Belo Horizonte: PUC-Minas, 2004.

FANON, F. Pele Negra Máscaras Brancas. Salvador: EDUFBA, 2008. 
FILHO, N. M. Maria Firmina. Fragmentos de uma vida. São Luís: s.e.,1975.

HALL, S. A identidade cultural na pós-modernidade. Tradução Tomaz Tadeu da Silva e Guaracira Lopes Louro. 11. ed. Rio de Janeiro: DP\&A, 2011.

LARAIA, R. de B. Cultura um conceito antropológico. Rio de Janeiro: Jorge Zahar Editor, 2014.

LE GOFF, J. História e Memória. Tradução Bernardo Leitão et al. 5. ed. Campinas: Editora da UNICAMP, 2003.

MEMMI, A. Retrato do colonizado precedido de Retrato do colonizador. Rio de Janeiro: Civilização Brasileira, 2007.

REIS, M. F. dos. Úrsula. A Escrava. Florianópolis: Editora Mulheres, 2004.

SAID, E. W. Orientalismo. O Oriente como intervenção do Ocidente. São Paulo: Editora Schwarcz, 2007.

SOUZA, N. S. Tornar-se negro ou as vicissitudes da identidade do negro brasileiro em ascensão social. Rio de Janeiro: Edições Graal, 1983. 